\title{
Hubungan Self Confidence dan Self Awareness dengan Komunikasi Efektif pada Mahasiswa
}

\section{Relationship between Self Confidence and Self Awareness with Effective Communication in Students}

\author{
Sirri Nahzatun Qowimah, Kays Jiddan Almahira, Delvina Alifah Rahma, Akmal Budi Satrio, Hanum \\ Miftahun Nuzul, Shofwatun Nada Yuliana Puteri, Nova Lusiana, Esti Novi Andyarini \\ Fakultas Psikologi dan Kesehatan, UIN Sunan Ampel Surabaya
}

\author{
esti_novi@uinsby.ac.id
}

\begin{abstract}
Abstrak
Tujuan dari penelitian ini adalah mengetahui hubungan antara self confidence dan self awareness terhadap variabel komunikasi efektif. Aspek tersebut menjadi hal yang sangat dibutuhkan bagi sumber daya manusia di era industri saat ini. Sampel dalam penelitian ini adalah 100 Mahasiswa Psikologi UINSA yang masih aktif dalam tahun ajaran 2020-2021. Analisa data yang digunakan menggunakan Regresi Linier Berganda. Hubungan self confidence dan self awareness dan komunikasi efektif adalah sangat signifikan, terlihat dari nilai $\mathrm{F}$ sebesar 17,268 dengan nilai $p$ adalah $0,000(<0,05)$. Variabel self confidence dan self awareness masing-masing memiliki nilai koefisien korelasi 0,393 dan 0,453 terhadap variabel Komunikasi. Hasil uji hipotesis didapatkan kesimpulan bahwa self confidence dan self awareness berhubungan positif terhadap variabel komunikasi efektif dan berdasarkan nilai korelasi dapat dikatakan bahwa self awareness lebih berpengaruh terhadap komunikasi efektif. R Square sebesar 0,263 menunjukkan self confidence dan self awareness secara simultan memberikan kontribusi dalam mempengaruhi komunikasi efektif sebesar 26,3\%, sedangkan sisanya 73,7\% dipengaruhi oleh variabel atau faktor lain.
\end{abstract}

Kata kunci: Self Confidence, Self Awareness, Komunikasi Efektif

\begin{abstract}
The purpose of this study is to determine the relationship between self-confidence and self-awareness of effective communication variables. This aspect is very much needed for human resources in the current industrial era. The sample in this study was 100 UINSA Psychology Students who are still active in the 2020-2021 academic year. Analysis of the data used using Multiple Linear Regression. The relationship between self-confidence and self-awareness and effective communication is very significant, it can be seen from the $F$ value of 17,268 with a $p$ value of $0.000(<0.05)$. The self-confidence and self-awareness variables each have a correlation coefficient of 0.393 and 0.453 for the Communication variable. The results of the hypothesis test concluded that self-confidence and self-awareness were positively related to the effective communication variable and based on the correlation value, it can be said that selfawareness has more influence on effective communication. $R$ Square of 0.263 shows that self confidence and self awareness simultaneously contribute to influencing effective communication by $26.3 \%$, while the remaining $73.7 \%$ is influenced by other variables or factors.
\end{abstract}

Keywords: Self Confidence, Self Awareness, Effective Communication 


\section{Pendahuluan}

Pandemi COVID-19 saat ini telah menimbulkan berberapa dampak bagi mahasiswa. Dengan diterapkannya protokol kesehatan, mahasiswa cenderung untuk lebih banyak beraktivitas di rumah, termasuk aktivitas kuliah secara daring, sehingga dapat mempengaruhi interaksi sosialnya. Dalam pembelajaran secara daring, terdapat pola pembelajaran yang berbeda sehingga turut mempengaruhi bentuk komunikasi dalam interaksi tersebut. Mahasiswa sebagai calon pemimpin bangsa dan kaum intelektual muda dituntut memiliki kemampuan berkomunikasi secara efektif, dalam pembelajaran maupun interaksi sosial lainnya. Situasi belajar di perguruan tinggi mengarahkan mereka lebih mandiri, aktif, dan berinisiatif dalam mencari informasi yang berhubungan dengan kemampuannya dalam berkomunikasi.kemampuan mahasiswa untuk berkomunikasi secara efektif maka dapat menunjang hasil pembelajarannya.

Menurut Mc Cartney dan Philips (Indrayati dkk., 2021) keterampilan komunikasi adalah metode yang paling penting dalam melakukan interaksi. Kemampuan komunikasi yang dipengaruhi oleh kemampuan dan penguasaan bahasa, akan menentukan kualitas interaksi sosial yang dilakukan individu. Pada mahasiswa, interaksi sosial dalam proses pembelajaran salah satunya berkaitan dengan keinginan mahasiswa untuk bertanya dan belajar di kelas maupun di luar kelas, dalam interaksi dengan guru, diskusi mahasiswa lain, maupun sumber belajar lainnya. Untuk memenuhi kebutuhan belajarnya tersebut perlu adanya dukungan atau bantuan orang lain yang dapat diperoleh melalui komunikasi efektif.

Komunikasi sebagai perilaku baik verbal dan non verbal dengan melibatkan 2 orang atau lebih, dapat dikatakan efektif jika dalam komunikasi tersebut dapat membuat perubahan perilaku orang yang berkomunikasi. Lebih jelas, menurut Jalaludin (Aries Suprapto, 2018). komunikasi dapat dikatakan efektif ketika menunjukkan tanda-tanda berikut: dapat menciptakan kesenangan, terdapat saling pengertian, dapat meningkatkan hubungan sosial yang baik, memberikan pengaruhi pada perilaku dan sikap, dan dapat menciptakan tindakan (Aries Suprapto, 2018).

Dalam praktek komunikasi efektif diperlukan adanya self confidence yang tinggi. Individu dengan self confidence tinggi akan cenderung dapat melakukan interaksi dengan orang lain melalui komunikasi yang baik. Menurut Siska (Sahputra dkk., 2016) orang yang memiliki self confidence cenderung mampu untuk melakukan interaksi dengan komunikasi yang baik. Self confidence akan mendukung perilaku seseorang untuk berani menggapai sesuatu yang menjadi tujuan di dalam hidupnya, karena orang yang percaya diri berarti yakin dengan kemampuan dan segala kelebihan yang ada dalam dirinya (Puspitasari \& Laksmiwati, 2012). Ketika seseorang memiliki keyakinan dengan kemampuannya, maka ia tidak akan ragu untuk berbagai informasi dan bertanya untuk melengkapi pengetahuanya.

Self confidence memiliki hubungan yang signifikan dengan kemampuan komunikasi interpersonal, semakin tinggi self confidence maka akan semakin tinggi pula kemampuan komunikasi interpersonal yang dimiliki (Mastiara, 2017). Keterampilan komunikasi saling berhubungan dengan self confidence. Jika siswa memiliki keterampilan interpersonal yang baik, maka self confidence siswa akan tinggi. Semakin baik keterampilan komunikasi interpersonal siswa, akan semakin tinggi pula self confidence siswa tersebut. (Dalam penelitian Purnomo dan Harmiyanto (2016))

Hal tersebut berbeda dengan penelitian yang dilakukan oleh Andriaty dkk. (2018) yang menyatakan bahwa tidak adanya hubungan antara self confidence dengan kemampuan komunikasi. Self confidence tentu bisa berubah-ubah, bisa meningkat dan bisa pula menurun. Perubahan ini terjadi karena ada faktor yang mempengaruhinya. Dalam penelitian Salim (2015), disebutkan bahwa terdapat dua faktor terpenting yang dapat mempengaruhi self confidence yaitu pengalaman pribadi dan dukungan positif. Dari perbedaan ini, peneliti tertarik untuk menguji hubungan antara kepercayaan diri dengan komunikasi efektif pada mahasiswa.

Selain self confidence, hal yang dapat berperan dalam tercapainya komunikasi efektif adalah kesadaran diri (self awareness). Self awareness penting dimiliki untuk berkomunikasi dan membangun kepercayaan pada orang lain (Govender, 2017).

. Menurut Goleman (Sastrawinata, 2011) self awareness adalah mengetahui apa yang dirasakan pada suatu saat kemudian digunakannya untuk memandu pengambilan keputusannya sendiri. Self awareness bukan hanya berkaitan dengan kepekaan terhadap diri sendiri dan emosinya, melainkan juga kepekaan terhadap keadaan serta lingkungan sekitar (Akbar dkk., 2018). Jadi, Self awareness merupakan kemampuan untuk mengenal, memilah perasaan pada diri sendiri, memahami apa yang 
sedang dirasakannya, mengapa hal tersebut dapat dirasakan, mengetahui apa penyebab munculnya perasaan tersebut, dan pengaruh perilaku tertentu terhadap orang lain.

Menurut Parek (Riyadi \& Hasanah, 2015) orang yang memiliki self awareness tinggi akan memiliki suatu sistem nilai dalam dirinya, dengan demikian orang tersebut dapat merefleksikan diri dan mengontrol dirinya sehingga ia dapat menunjukkan perilaku sesuai dengan hal positif yang ia yakini. Kemampuan kontrol diri dalam self awarenee ini mempengaruhi bentuk komunikasinya dengan orang lain. Hal ini dikuatkan oleh penelitian Fadlillah (Fadlillah, 2018), bahwa terdapat hubungan yang positif antara peran komunikasi organisasi dengan self awareness, semakin tinggi peran komunikasi organisasi, maka akan semakin tinggi self awareness-nya, demikian pula sebaliknya

Self confidence dan self awareness merupakan dua aspek penting dalam komunikasi efektif generasi muda, agar mereka memiliki potensi dan kompetensi yang dibutuhkan dalam rangka membentuk diri menjadi sumber daya manusia yang unggul dan berdaya saing, sehingga perlu adanya penelitian korelasi self confidence dan self awareness baik secara parsial ataupun simultan dengan komunikasi efektif pada mahasiswa psikologi.

\section{Metode Penelitian}

Penelitian ini menggunakan metode kuantitatif korelasional. Populasi pada penelitian ini adalah mahasiswa Psikologi UIN Sunan Ampel Surabaya yang. Teknik sampling yang digunakan pada penelitian ini adalah simple random sampling dimana pengambilan sampel dilakukan dengan tidak memperhatikan strata dalam populasi penelitian, melainkan sampel diambil secara acak. Dengan mempertimbangkan teori Frankel dan Wallen (1993) yang menyarankan besar sampel minimum 50 subjek dan hasil penyebaran kuesioner kepada mahasiswa psikologi UIN Sunan Ampel Surabaya diperoleh 100 responden. Data dalam penelitian ini diperoleh dengan menggunakan kuesioner yang mana merupakan hasil adaptasi, diantaranya skala self confidence dari penelitian Khoriroh (2018) berjumlah 15 butir item yang didasarkan dari berbagai teori para ahli. Yang dapat disimpulkan bahwa kepercayaan diri adalah penilaian individu akan kesanggupan dan keterampilan yang dimilikinya sehingga menimbulkan keyakinan untuk bertindak dalam area yang lebih luas dari sebelumnya; skala self awareness dari penelitian oleh Hilapok (2017) berjumlah 14 butir yang didasarkan pada lima aspek, yaitu attention, wakefulness, recall of knowledge, dan emotive; dan komunikasi efektif dari penelitian Ahdiyat (2013) berjumlah 15 butir item yang dikembangkan menjadi indikator diantaranya, respect, empati, humble, clarity, audibel, meningkatnya hubungan antarpribadi antar individu yang terlibat dalam komunikasi antarpribadi, dan melaksanakan pesan secara sukarela. Model skala yang digunakan pada penelitian ini adalah model likert.

Sedangkan untuk analisis datanya penelitian ini mengunakan teknik analisis regresi linier berganda. Regresi linier berganda digunakan untuk memprediksi hubungan antara lebih dari dua variabel. Sebelum melakukan analisis dengan regresi linier berganda maka akan dilakukan uji prasyarat terlebih yang meliputi: uji Normalitas, uji Linearitas, uji Multikolinearitas, dan uji Heteroskedastisitas. Uji prasyarat ini digunakan untuk dapat mengetahui apakah hasil dari analisis data untuk uji hipotesis dapat dilanjutkan atau tidak.

Uji Normalitas dilakukan dengan Kolmogorov-Smirnov. Data variabel dikatakan berdistribusi normal jika nilai signifikansinya $\mathrm{p}>0,05$. Nilai signifikansi sebesar $0,130(\mathrm{p}>0,05)$ menunjukkan data berdistribusi normal. Uji Linearitas dilakukan dengan menggunakan uji compare mean. Data dapat dikatakan memiliki hubungan yang linear apabila nilai signifikansi $<0,05$. Variabel self confidence dengan komunikasi efektif menghasilkan nilai signifikansi $0,000(\mathrm{p}<0,05)$. Variabel self awareness dengan komunikasi efektif menghasilkan nilai signifikansi 0,000 ( $p<0,05$ ). Dari kedua hasil tersebut menunjukkan bahwa terdapat hubungan yang linear antara self confidence dan self awareness dengan komunikasi efektif. Uji Multikolinearitas dilakukan dengan melihat nilai Tolerance dan VIF. Jika nilai VIF $\leq 10$ dan nilai Tolerance $\geq 0,1$, maka dinyatakan tidak terjadi multikolinearitas. Diperoleh nilai Tolerance sebesar 0,858 (>0,1) dan nilai VIF sebesar 1,165 (< 10). Hal ini menunjukkan tidak ada multikolinearitas. Uji Heteroskedastisitas diukur dengan menggunakan uji Glejser. Jika nilai signifikansi < 0,05, maka sesuai dengan dasar pengambilan keputusan dalam uji Glejser bahwasannya terjadi gejala heteroskedastisitas dalam model regresi. Variabel bebas dalam penelitian ini dapat disimpulkan bahwa terjadi gejala heteroskedastisitas dalam model regresi. Hal ini ditunjukkan dengan 
nilai signifikansi pada variabel self confidence sebesar $0,028(\mathrm{p}<0,05)$ dan variabel self awareness sebesar $0,053(p<0,05)$.

\section{Hasil Penelitian}

Penelitian ini dilakukan di lingkungan Fakultas Psikologi dan Kesehatan UIN Sunan Ampel Surabaya, untuk melihat self awareness, self confidence, dan komunikasi efektif pada mahasiswa Psikologi UIN Sunan Ampel Surabaya. Adapun hasil yang didapat adalah sebagai berikut.

Tabel 1. Descriptive Statistics

\begin{tabular}{lcrr}
\hline & \multicolumn{3}{c}{ Descriptive Statistics } \\
\cline { 2 - 4 } & Mean & Std. Deviation & $\mathrm{N}$ \\
\hline Komunikasi Efektif & 43.07 & 4.036 & 100 \\
Self Confidence & 43.50 & 4.069 & 100 \\
Self Awareness & 45.41 & 4.761 & 100 \\
\hline
\end{tabular}

Tabel di atas memberikan informasi mengenai besarnya mean (rata-rata) dan simpangan baku (standard deviation) setiap variabel. Rata-rata komunikasi efektif adalah 43,07. Rata-rata self confidence adalah 43,50; dan rata-rata self awareness adalah 45,51. Simpangan baku komunikasi efektif adalah 4,036. Simpangan baku self confidence adalah 4,069; dan simpangan baku self awareness adalah 4,761 .

Tabel 2. Correlation

\begin{tabular}{|c|c|c|c|c|}
\hline & & \multicolumn{3}{|l|}{ Correlations } \\
\hline & & Komunikasi Efektif & Self Confidence & Self Awareness \\
\hline \multirow[t]{3}{*}{ Pearson Correlation } & Komunikasi Efektif & 1.000 & .393 & .453 \\
\hline & Self Confidence & .393 & 1.000 & .376 \\
\hline & Self Awareness & .453 & .376 & 1.000 \\
\hline \multirow[t]{3}{*}{ Sig. (1-Tailed) } & Komunikasi Efektif & & .000 & .000 \\
\hline & Self Confidence & .000 & $\cdot$ & .000 \\
\hline & Self Awareness & .000 & .000 & \\
\hline \multirow[t]{3}{*}{$\mathrm{N}$} & Komunikasi Efektif & 100 & 100 & 100 \\
\hline & Self Confidence & 100 & 100 & 100 \\
\hline & Self Awareness & 100 & 100 & 100 \\
\hline
\end{tabular}

Berdasarkan tabel korelasi di atas, interpretasinya adalah:

a) Nilai korelasi self confidence dengan komunikasi efektif adalah sebesar 0,393, dengan nilai $p$ value (.sig) sebesar 0,000. Dengan demikian dapat dikatakan terdapat hubungan yang cukup kuat (dengan arah positif) dan signifikan ( $p$ value $<0,05$ ) antara self confidence dengan komunikasi efektif.

b) Nilai korelasi self awarness dengan komunikasi efektif adalah sebesar 0,453, dengan nilai $p$ value (.sig) sebesar 0,000. Dengan demikian dapat dikatakan terdapat hubungan yang cukup kuat (dengan arah positif) dan signifikan ( $p$ value $<0,05)$ antara self awarness dengan komunikasi efektif.

Secara teoritis, berdasarkan nilai korelasi dapat dikatakan bahwa self awareness lebih berpengaruh terhadap komunikasi efektif. 
Tabel 3. Koefisien Determinasi

Model Summary

\begin{tabular}{|c|c|c|c|c|c|c|c|c|c|}
\hline \multirow[b]{2}{*}{$\begin{array}{l}\text { Mode } \\
1\end{array}$} & \multirow[b]{2}{*}{$\mathrm{R}$} & \multirow[b]{2}{*}{$\mathrm{R}$ Square } & \multirow[b]{2}{*}{$\begin{array}{l}\text { Adjusted } \\
\text { R Square }\end{array}$} & \multirow[b]{2}{*}{$\begin{array}{r}\text { Std. Error Of The } \\
\text { Estimate }\end{array}$} & \multicolumn{5}{|c|}{ Change Statistics } \\
\hline & & & & & $\begin{array}{r}\mathrm{R} \text { Square } \\
\text { Change }\end{array}$ & F Change & Df1 & Df2 & $\begin{array}{r}\text { Sig. F } \\
\text { Change }\end{array}$ \\
\hline 1 & $.512^{\mathrm{a}}$ & .263 & .247 & 3.501 & .263 & 17.268 & 2 & 97 & .000 \\
\hline
\end{tabular}

a. Predictors: (Constant), Self Awareness, Self

Confidence

Berdasarkan nilai $\mathrm{R}$, dapat diketahui bahwa besarnya koefisien regresi antara self confidence dan self awareness dengan komunikasi efektif adalah sebesar 0,512. R Square sebesar 0,263 menunjukkan self confidence dan self awareness hanya memberikan kontribusi dalam mempengaruhi komunikasi efektif sebesar 26,3\%, sedangkan sisanya 73,7\% dipengaruhi oleh variabel atau faktor lain.

Tabel 4. Anova

\begin{tabular}{llrrrrr}
\hline \multicolumn{6}{c}{ ANOVA $^{\mathrm{b}}$} \\
\hline Model & & Sum of Squares & df & Mean Square & F & Sig. \\
\hline 1 & Regression & 423.383 & 2 & 211.691 & 17.268 & $.000^{\text {a }}$ \\
& Residual & 1189.127 & 97 & 12.259 & & \\
& Total & 1612.510 & 99 & & & \\
\hline
\end{tabular}

a. Predictors: (Constant), Self Awareness, Self Confidence

b. Dependent Variable: Komunikasi Efektif

Tabel diatas memperkuat interpretasi bahwa hubungan self confidence dan self awareness dan komunikasi efektif adalah sangat signifikan, terlihat dari nilai $\mathrm{F}$ sebesar 17,268 dengan nilai $p$ adalah $0,000(<0,05)$, yang berarti hubungan tersebut adalah sangat signifikan.

Tabel 5. Koefisien

\begin{tabular}{|c|c|c|c|c|c|c|}
\hline \multicolumn{7}{|c|}{ Coefficients $^{\mathrm{a}}$} \\
\hline & & \multicolumn{2}{|c|}{$\begin{array}{l}\text { Unstandardized } \\
\text { Coefficients }\end{array}$} & $\begin{array}{l}\text { Standardized } \\
\text { Coefficients }\end{array}$ & \multirow[b]{2}{*}{$\mathrm{t}$} & \multirow[b]{2}{*}{ Sig. } \\
\hline \multicolumn{2}{|c|}{ Model } & B & Std. Error & Beta & & \\
\hline \multirow[t]{3}{*}{1} & (Constant) & 18.217 & 4.320 & & 4.217 & .000 \\
\hline & Self Confidence & .257 & .093 & .259 & 2.754 & .007 \\
\hline & Self Awareness & .301 & .080 & .355 & 3.774 & .000 \\
\hline
\end{tabular}

a. Dependent Variable: Komunikasi Efektif

Tabel di atas menunjukkan persamaan garis regresi. Rumus persamaan garis regresi berganda secara umum adalah:

$$
\begin{aligned}
& \hat{Y}=a+b_{1} X_{1}+b_{2} X_{2} \\
& \hat{Y}=18,217+0,257 X_{1}+0,301 X_{2}
\end{aligned}
$$

Tabel di atas juga memberikan informasi bahwa apabila self confidence dan self awareness diuji secara sendiri-sendiri ternyata mempunyai hubungan yang signifikan dengan komunikasi efektif. Hal ini ditunujukkan dengan nilai $p$ value self confidence sebesar $0,007(<0,025)$ dan self awareness sebesar $0,000(<0.025)$. 
Tabel 6. Self Confidence dan Self Awareness terhadap Komunikasi Efektif berdasarkan Jenis Kelamin

\begin{tabular}{|c|c|c|c|c|c|c|c|c|c|c|c|c|}
\hline \multirow{3}{*}{$\begin{array}{l}\begin{array}{l}\text { Jenis } \\
\text { Kelamin }\end{array} \\
\text { Perempuan }\end{array}$} & \multicolumn{4}{|c|}{ Self Confidence } & \multicolumn{4}{|c|}{ Self Awareness } & \multicolumn{4}{|c|}{ Komunikasi Efektif } \\
\hline & \multicolumn{2}{|c|}{ Sedang } & \multicolumn{2}{|c|}{ Tinggi } & \multicolumn{2}{|c|}{ Sedang } & \multicolumn{2}{|c|}{ Tinggi } & \multicolumn{2}{|c|}{ Sedang } & \multicolumn{2}{|c|}{ Tinggi } \\
\hline & 19 & $22.1 \%$ & 67 & $77.9 \%$ & 8 & $9.3 \%$ & 78 & $90.7 \%$ & 12 & $14.0 \%$ & 74 & $86.0 \%$ \\
\hline Laki-Laki & 6 & $42.9 \%$ & 8 & $57.1 \%$ & 2 & $14.3 \%$ & 12 & $85.7 \%$ & 10 & $71.4 \%$ & 4 & $28.6 \%$ \\
\hline
\end{tabular}

Tabel di atas merupakan tabel silang yang menunjukkan hubungan antara jenis kelamin dengan self confidence, self awareness, dan komunikasi efektif. Jumlah responden perempuan sebanyak 86 dan laki-laki sebanyak 14. Tidak terdapat hubungan variabel Self confidence dengan jenis kelamin dimana kategori tinggi pada responden jenis kelamin perempuan sebesar 77,9 \% dan kategori rendah pada lakilaki $42,9 \%$.Tidak terdapat hubungan variabel Self awareness dengan jenis kelamin dimana kategori tinggi pada responden jenis kelamin perempuan sebesar 90,7 \% dan kategori rendah pada laki-laki $57,1 \%$.

Pada variabel komunikasi efektif perempuan sebagian besar pada kategori tinggi (86, \%) dan laki-laki dengan komunikasi efektif rendah juga tinggi yaitu $71,4 \%$. dapat disimpulkan komunikasi efektif mahasiswa perempuan cenderung lebih tinggi dibandingkan laki-laki.

Tabel 7. Self Confidence dan Self Awareness terhadap Komunikasi Efektif berdasarkan Usia

\begin{tabular}{|c|c|c|c|c|c|c|c|c|c|c|c|c|}
\hline \multirow{3}{*}{$\begin{array}{l}\text { Usia } \\
17-19\end{array}$} & \multicolumn{4}{|c|}{ Self Confidence } & \multicolumn{4}{|c|}{ Self Awareness } & \multicolumn{4}{|c|}{ Komunikasi Efektif } \\
\hline & \multicolumn{2}{|c|}{ Sedang } & \multicolumn{2}{|c|}{ Tinggi } & \multicolumn{2}{|c|}{ Sedang } & \multicolumn{2}{|c|}{ Tinggi } & \multicolumn{2}{|c|}{ Sedang } & \multicolumn{2}{|c|}{ Tinggi } \\
\hline & 2 & $7.7 \%$ & 24 & $92.3 \%$ & 3 & $11.5 \%$ & 23 & $88.5 \%$ & 4 & $15.4 \%$ & 22 & $84.6 \%$ \\
\hline $20-22$ & 21 & $33.9 \%$ & 41 & $66.1 \%$ & 6 & $9.7 \%$ & 56 & $90.3 \%$ & 17 & $27.4 \%$ & 45 & $72.6 \%$ \\
\hline $23-25$ & 2 & $16.7 \%$ & 10 & $83.3 \%$ & 1 & $8.3 \%$ & 11 & $91.7 \%$ & 1 & $8.3 \%$ & 11 & $91.7 \%$ \\
\hline
\end{tabular}

Tabel di atas merupakan tabel silang yang menunjukkan hubungan antara usia dengan self confidence, self awareness, dan komunikasi efektif. Jumlah responden usia 17-19 tahun sebanyak 26, usia 20-22 tahun sebanyak 62, dan berada pada usia 23-25 tahun sebanyak 12. Pada variabel self confidence kategori tinggi adalah pada usia 17 -19 tahun sebesar 92,3\% dan dan variabel komunikasi efektif kategori tinggi sebagian besar pada usia 23- 25 tahun $91,7 \%$. Pada variabel self awareness semakin tinggi usia mahasiswa maka semakin banyak responden pada kategori tinggi, dimana pada adalah usia $23-25$ tahun $(91,7 \%)$ kategori tinggi.

\section{Pembahasan}

Dari hasil penelitian, diketahui terdapat hubungan positif dan signifikan ( $p$ value $<0,05)$ antara self confidence dengan komunikasi efektif, artinya semakin tinggi self confidence maka akan semakin baik komunikasi. Hasil tersebut sesuai dengan penelitian yang dilakukan Anggraini (Anggraini, 2010) pada siswa SMA Negeri 8 Surakarta, hasil penelitian menunjukkan terdapat hubungan positif yang signifikan antara self confidence dan komunikasi interpersonal dengan interaksi sosial. Begitupun dengan penelitian Sahputra (Sahputra dkk., 2016) pada siswa SMA Negeri 8 Padang yang menunjukkan self confidence berkontribusi secara signifikan terhadap komunikasi interpersonal sebesar $19,6 \%$. Dengan begitu dapat disimpulkan bahwa sangat penting untuk membentuk self confidence agar lebih mudah untuk beradaptasi dan berkomunikasi dengan baik terhadap lingkungan sosialnya.

Self confidence adalah salah satu aspek kepribadian yang penting dalam kehidupan seseorang. Menurut McClelland percaya diri adalah suatu perasaan dan keyakinan terhadap kemampuan yang dimiliki untuk dapat meraih kesuksesan dengan berpijak pada usahanya sendiri dan mengembangkan penilaian yang positif bagi dirinya sendiri maupun lingkungannya sehingga, seseorang dapat tampil dengan penuh keyakinan dan mampu menghadapi segala sesuatu dengan tenang (Fitri dkk., 2018). Self confidence berperan penting dalam kehidupan seseorang. Self confidence merupakan salah satu faktor 
utama kesuksesan seseorang untuk menjalani kehidupannya dimasa depan dengan penuh optimisme dan kunci kehidupan yang berhasil dan bahagia (Fitri dkk., 2018). Seseorang dalam menjalani kehidupannya tidak bisa lepas dari orang lain. Karena, kehidupan seorang manusia merupakan makhluk sosial yang dimana keberlangsungan hidupnya tidak bisa lepas dari keberadaan oran lain. Untuk dapat menjalani hubungan yang baik, maka self confidence memegang peran penting dalam kesuksesan seseorang dalam menjalani sebuah kehidupan (Mirhan, 2016).

Seseorang yang memiliki self confidence tinggi, maka memiliki perasaan positif terhadap dirinya. Orang dengan self confidence tinggi bukanlah orang yang hanya merasa mampu tetapi orang yang mengetahui bahwa dirinya mampu berdasarkan pengalaman dan perhitungannya. Begitupun sebaliknya, seseorang yang memiliki self confidence rendah, akan memiliki perasaan negatif terhadap dirinya, memiliki keyakinan lemah terhadap kemampuannya, dan tidak memiliki keberanian karena dihantui dengan rasa takut. Oleh karena itu self confidence dipandang sebagai salah satu aspek penting dalam pembentukan kepribadian seseorang (Vega dkk., 2019). Devito (Andini dkk., 2019) mengatakan bahwasannya self confidence adalah kepercayaan seseorang yang ada pada dirinya, komunikator yang efektif dan kompeten, serta kemampuan seseorang untuk memproyeksikan ketika berinteraksi dengan orang lain.

Karakteristik usia juga merupakan aspek yang dapat mempengaruhi self confidence, yang dibuktikan dengan hasil penelitian oleh Nurika bahwa terdapat hubungan kausalitas antara self confidence dan usia individu (Nurika, 2016). Berbeda dengan hasil penelitian yang didapatkan bahwa self confidence tidak berhubungan dengan jenis keamin dan umur. Seseorang yang memiliki self confidence tinggi, maka memiliki perasaan positif terhadap dirinya. Orang dengan kepercayaan diri tinggi bukanlah orang yang hanya merasa mampu tetapi orang yang mengetahui bahwa dirinya mampu berdasarkan pengalaman, perhitungannya ataupun gendernya. Begitupun sebaliknya, seseorang yang memiliki kepercayaan diri rendah, akan memiliki perasaan negative terhadap dirinya, memiliki keyakinan lemah terhadap kemampuannya, dan tidak memiliki keberanian karena dihantui dengan rasa takut. Oleh karena itu kepercayaan diri dipandang sebagai salah satu aspek penting dalam pembentukan kepribadian seseorang (Vega dkk., 2019).

Terdapat hubungan yang cukup (dengan arah positif) dan signifikan $(p$ value $<0,05)$ antara self awarness dengan komunikasi efektif, sehingga dapat diartikan bahwa terdapat korelasi antara variabel self awareness dengan komunikasi efektif, dengan nilai korelasi sebesar 0,453. Hasil ini sejalan dengan penelitian yang dilakukan oleh Fitriana dkk. (2018) yang menyatakan bahwa variabel motivasi, variabel self awareness dan variabel komunikasi secara simultan memiliki pengaruh terhadap disiplin kerja karyawan PDAM Kabupaten Ponorogo. Begitu pula dengan penelitian Fadlillah (Fadlillah, 2018), didapatkan hasil korelasi pearson 0,404 dan signifikansi sebesar 0,01 yang berarti terdapat hubungan positif antara peran komunikasi organisasi dengan self awareness. Maka dapat diartikan bahwa semakin tinggi peran komunikasi organisasi, maka semakin tinggi pula self awareness.

Self awareness adalah pokok yang penting untuk menunjukkan kejelasan serta pemahaman tentang perilaku diri. Self awareness juga merupakan kecerdasan dimana seseorang akan menempati dirinya pada situasi dan kondisi tertentu dan apa yang harus ia lakukan. Contohnya dalam dunia pendidikan karakter, pendidikan digunakan karena self awareness akan membentuk karakter yang ada dalam diri seseorang. Para ahli mempunyai berbagai pendapat mengenai self awareness, menurut Brandberry Greaves (2005), self awareness adalah kemampuan untuk memahami emosi diri sendiri secara tepat dan akurat dalam berbagai situasi secara valid dan reliable. Orang yang memiliki self awareness yang tinggi memiliki sikap positif di dalam menjalani kehidupan. Sementara itu, Goleman (2001) menyatakan bahwa self awareness adalah mengetahui apa yang dirasakan pada suatu saat yang menggunakannya untuk memandu pengambilan keputusannya sendiri. Selain itu self awareness juga berarti menetapkan tolak ukur yang realistis atas kemampuan diri dan self confidence yang kuat serta memungkinkan kita untuk berhubungan dengan emosi, pikiran, dan tindakan. Jadi dapat disimpulkan bahwa self awareness bukan hanya peka terhadap diri sendiri dan emosinya melainkan peka terhadap keadaan serta lingkungan sekitar (Akbar dkk., 2018).

Self awareness adalah kemampuan untuk mengenal dan memilah-milah perasaan pada diri sendiri, memahami hal yang sedang dirasakan, mengapa hal tersebut bisa dirasakan, dan mengetahui penyebab munculnya perasaan tersebut, serta pengaruh perilaku terhadap orang lain. Self awarenesS sangat tepat bagi kelompok remaja, karena memberikan mereka kesempatan untuk menyampaikan gagasan, perasaan, permasalahan, dan melepas keragu-raguan pada dirinya. Karena pada kenyataanya seorang remaja akan senang berbagi pada teman sebayanya akan pengalaman dan keluhan-keluhan 
yang dirasakan (Maharani \& Mustika, 2016). Sejalan dengan penelitian McQueen (Mitayani, 2017) pada perawat, menyatakan bahwa perawat mampu bertindak dan berkomunikasi dengan cara yang tepat dan penuh akan kepedulian apabila perawat memiliki self awareness yang baik. Begitu pula sebaliknya, apabila perawat memiliki self awareness yang kurang baik atau bahkan tidak baik maka perawat akan bertindak dan berkomunikasi dengan penuh emosi tanpa ada rasa peduli terhadap pasiennya.

Berdasarkan penelitian juga didapatkan bahwa self awareness cenderung semakin tinggi pada usia yang juga semakin tinggi tetapi self awareness tidak berhubungan dengan jenis kelamin. Hal ini sejalan dengan penelitian yang dilakukan oleh (Richardson, McKay \& Ponsford, 2015) menyebutkan bahwa faktor yang mempengaruhi kesadaran diri yaitu usia, jika usia lanjut memiliki hubungan dengan peningkatan kesadaran diri. Meski begitu, tidak ditemukan penelitian terkait hubungan antara jenis kelamin dengan kesadaran diri.

Selain itu, ditemukan juga bahwa latar belakang pendidikan dan etnis juga berhubungan dengan kesadaran diri. Burke (2011) menyebutkan bahwa self-awareness dapat dipengaruhi oleh beberapa faktor diantaranya kebudayaan, pendidikan, gender dan pengalaman sebelumnya. Sementara itu dalam sebuah penelitian yang dilakukan oleh Achmad Kusyairi dan Widya Addiarto (2019) ditemukan bahwa faktor yang dapat mempengaruhi self-awareness adalah pendapatan, ras/suku, jenis kelamin, kepemilikan, usia, pendidikan dan pengalaman.

Orang yang memiliki kesadaran diri tinggi akan dapat mengendalikan dirinya (mengontrol perilakunya) dengan lebih baik dan tidak akan mengalami hambatan dalam menjalani hubungan dengan orang lain dan lingkungan sehingga hal ini akan sangat berpengaruh terhadap cara berkomunikasi efektif kepada orang lain dan lingkungannya. Orang yang memiliki kesadaran diri tinggi akan mampu merefleksikan diri dan berperilaku sesuai nilai-nilai positif yang dianutnya.

Dari hasil uji hipotesis, diketahui nilai $\mathrm{F}$ sebesar 17,268 dengan nilai $p$ adalah 0,000 $(<0,05)$, yang berarti terdapat hubungan yang sangat signifikan antara self confidence dan self awareness dengan komunikasi efektif pada mahasiswa. Hal ini dikuatkan dengan nilai $\mathrm{R}$ Square sebesar 0,263 menunjukkan self confidence dan self awareness secara simultan memberikan kontribusi dalam mempengaruhi komunikasi efektif sebesar 26,3\%.

Komunikasi merupakan segala perilaku baik verbal maupun non verbal yang melibatkan 2 orang atau lebih. Komunikasi dapat dikatakan efektif apabila komunikasi tersebut mampu membuat perubahan perilaku pada orang yang telibat dalam komunikasi itu. Komunikasi efektif bertujuan untuk membuat pesan yang disampaikan menjadi mudah dipahami dengan bahasa yang jelas antara komunikator dan komunikan sehingga terjadi umpan balik yang baik (Aries Suprapto, 2018). Menurut Jalaludin (2008) komunikasi bisa dikatakan efektif jika mempunyai tanda-tanda sebagai berikut: menciptakan kesenangan, saling pengertian, mampu meningkatkan hubungan sosial yang apik, berpengaruh terhadap perilaku dan sikap, dan juga menciptakan tindakan (Aries Suprapto, 2018).

Mc Cartney dan Philips (Indrayati dkk., 2021) menyampaikan bahwa keterampilan komunikasi merupakan metode yang paling penting untuk melakukan interaksi. Selain itu juga kemampuan dan penguasaan bahasa yang dimiliki individu akan menentukan kualitas interaksi sosial yang dilakukan. Adapun individu yang mampu mengkomunikasikan keinginan tujuan dalam berinteraksi maka orang tersebut mampu berkomunikasi secara efektif. Tentunya ada proses guna menacapai tujuan komunikasi efektif. Proses komunikasi efektif merupakn serangkaian kegiatan yang dilakukan dimana terdapat tahapan penyampaian pesan, penggunaan media, dan penerima pesan. Seperti halnya dalam penelitian Indrayati dkk., (Indrayati dkk., 2021) hasil pre test tentang komunikasi efektif mayoritas kurang $(59,5 \%)$ kemudian setelah itu dilakukan pendidikan tentang komunikasi efektif dan terjadi perubahan pengetahuan tentang komunikasi efektif (92,9\%).

Hasil penelitian menunjukan kecenderungan komunikasi efektif pada perempuan lebih tinggi dari laki-laki, selaras dengan hasil penelitian yang menyatakan komunikasi interpersonal antara lakilaki dan perempuan berbeda (Hasanah, 2015), yang menunjukkan bahwa jenis kelamin memang dapat mempengaruhi kemampuan interpersonal individu. Kemudian, dalam artikel oleh Suhanti dkk disebutkan bahwa usia dewasa dan prestasi belajar dapat mempengaruhi kemampuan komunikasi interpersonal (Suhanti dkk., 2018). Ini menunjukkan bahwa usia dan tingkatan ilmu yang didapat dalam perwujudan tingkat semester yang telah ditempuh dapat menjadi faktor yang mempengaruhi kemampuan komunikasi interpersonal.Komunikasi efektif dapat terjadi ketika si penerima dapat memahami dengan baik informasi yang diberikan oleh pengirim (Osakinle dan Okafor, 2013). komunikasi efektif sebagai tindakan dan kegiatan yang digunakan untuk mempertahankan hubungan 
sesuai dengan apa yang diinginkan. Implikasi dari tindakan ini dikonseptualisasikan dengan perilaku strategis dan rutin yang mencakup komunikasi verbal dan nonverbal.

Self confidence adalah rasa percaya diri yang biasanya digunakan sebagai jaminan diri dalam penilaian pribadi, kemampuan, dan kekuatan individu serta mempercayai kemampuannya untuk mencapai beberapa tujuan (Diniyah dkk., 2018). Menurut Lauster (Amri, 2018). Self confidence merupakan suatu sikap atau keyakinan atas kemampuan diri sendiri, sehingga dalam tindakantindakannya individu tidak terlalu cemas, merasa bebas untuk melakukan hal-hal yang sesuai dengan keinginan dan tanggung jawab atas perbuatannya, sopan dalaem berinteraksi dengan orang lain, dan memiliki dorongan prestasi, serta dapat mengenal kelebihan dan kekurangan diri sendiri. Individu dengan rasa self confidence tinggi biasanya tidak mengalami kesulitan dalam berkomunikasi (Andriaty dkk., 2018).

Self confidence memiliki pengaruh yang cukup besar dalam proses komunikasi efektif. Dengan kata lain self confidence memiliki hubungan yang erat dengan kemampuan individu dalam berkomunikasi. Individu yang percaya diri cenderung tidak mengalami kesulitan dalam menghadapi lingkungan baru. Begitu pula sebaliknya, individu yang merasa tidak percaya diri maka ia akan mengalami kesulitan untuk mengkomunikasikan gagasan-gagasannya pada orang lain dan menghindar untuk berbicara di depan umum (Demak dkk., 2019). Pearson menyatakan ada empat faktor komunikasi efektif yaitu terbuka, asertif, mendengar aktif, dan empati. Terbuka dan asertif menggambarkan self confidence individu, sedangkan mendengar aktif dan empati menggambarkan sikap perhatian dalam berkomunikasi. Jadi, salah satu faktor yang mempengaruhi komunikasi efektif adalah self confidence (Andriaty dkk., 2018).

Self confidence dan self awareness merupakan faktor penting yang dapat mengembangkan kemampuan komunikasi interpersonal yang menunjang pengembangan karir yang diinginkan. Dalam teori psikoanalisis, ada istilah proyeksi, yaitu dimana individu mengeksternalisasikan pengalaman subjektifnya secara tidak sadar. Individu yang memiliki self confidence dan self awareness yang tinggi biasanya merupakan individu yang mudah bergaul, ramah, menerima diri apa adanya, dan pandai memahami orang. Individu yang seperti ini cenderung memberikan penilaian yang positif pada orang lain, yang menurut Bosson dan Maslow (1955), hal ini disebut dengan leniency effect (Rakhmat, 2011). Kepribadian seperti inilah yang mampu digunakan sebagai landasan untuk membangun komunikasi efektif.

Dari nilai R-Square sebesar 0,263 diketahui self confidence dan self awareness memberikan kontribusi sebesar 26,3\% dalam mempengaruhi komunikasi efektif, sisanya sebesar 73,7\% dipengaruhi oleh variabel atau faktor lain. Variabel-variabel ini dapat diteliti lebih lanjut oleh peneliti berikutnya.

\section{Kesimpulan}

Hasil penelitian menunjukkan korelasi positif antara self confidence dan self awareness terhadap komunikasi efektif pada mahasiswa Prodi Psikologi UIN Sunan Ampel Surabaya. Berdasarkan nilai korelasi dapat dikatakan bahwa self awareness lebih berpengaruh terhadap komunikasi efektif. Secara parsial tingkat keeratan hubungan antara self confidence dan self awareness terhadap komunikasi efektif menunjukkan koefisien korelasi 0,393 dan 0,453 yang berarti cukup kuat. Secara simultan, self confidence dan self awareness memberikan kontribusi dalam mempengaruhi komunikasi efektif sebesar $26,3 \%$ sedangkan sisanya $73,7 \%$ dipengaruhi oleh variabel atau faktor lain. Variabel self confidence dan self awareness dapat dijadikan prediktor komunikasi efektif mahasiswa.

Untuk mengembangkan kemampuan berkomunikasi efektif pada mahasiswa, bagi perguruan tinggi dan mahasiswa, perlu melakukan upaya-upaya untuk mengembangkan self confidence dan self awarenes. Bagi peneliti selanjutnya, dapat mempertimbangkan untuk meneliti variabel- variabel lainnya yang mempengaruhi kemampuan komunikasi efektif dengan penelitian morelasional mapuan dengan penelitian eksperimen yang menguji treatmen tertentu untuk meningkatkan komunikasi efektif mahasiswa. 


\section{Daftar Pustaka}

Ahdiyat, M. (2013). Meningkatkan Efektivitas Komunikasi Antarpribadi Melalui Layanan Konseling Kelompok pada Siswa Kelas VII C SMP Negeri 3 Kendal Tahun Ajaran 2012-2013 [Under Graduates, Universitas Negeri Semarang]. https://lib.unnes.ac.id/17209/.

Akbar, M. Y. A., Amalia, R. M., \& Fitriah, I. (2018). Hubungan Relijiusitas dengan Self Awareness Mahasiswa Program Studi Bimbingan Penyuluhan Islam (Konseling) UAI. Jurnal Al-Azhar Indonesia Seri Humaniora, 4(4), 265-270. https://doi.org/10.36722/sh.v4i4.304.

Amri, S. (2018). Pengaruh Kepercayaan Diri (Self Confidence) Berbasis Ekstrakurikuler Pramuka terhadap Prestasi Belajar Matematika Siswa SMA Negeri 6 Kota Bengkulu. Jurnal Pendidikan Matematika Raflesia, 3(2), 156-170. https://doi.org/10.33449/jpmr.v3i2.7520.

Andini, R. N., Widiastuti, R., \& Pratama, M. J. (2019). Hubungan Kepercayaan Diri dengan Komunikasi Interpersonal. ALIBKIN (Jurnal Bimbingan Konseling), 7(2), Article 2. http://jurnal.fkip.unila.ac.id/index.php/ALIB/article/view/18232.

Andriaty, S. N., Hartaty, N., \& Adelia, A. (2018). Hubungan Kepercayaan Diri Dengan Kemampuan Komunikasi Dalam Diskusi PBL Pada Mahasiswa Program Studi Pendidikan Dokter Universitas Abulyatama Angkatan 2016. Jurnal Aceh Medika, 2(1), 58-64.

Anggraini, W. D. (2010). Hubungan Antara Kepercayaan Diri dan Komunikasi Interpersonal Dengan Interaksi Sosial Pada Remaja Siswa Kelas XI SMA Negeri 8 Surakarta. Universitas Negeri Surakarta, 2(4).

Aries Suprapto, H. (2018). Pengaruh Komunikasi Efektif Untuk Meningkatkan Hasil Belajar Mahasiswa. Khazanah Pendidikan, 11(1). https://doi.org/10.30595/jkp.v11i1.2308.

Demak, I. P. K., Juraejo, F. A. J., \& Rupawan, I. K. (2019). Hubungan Kepercayaan Diri dalam Kemampuan Komunikasi pada Metode Pembelajaran Problem Based Learning Mahasiswa Kedokteran Universitas Tadulako. Healthy Tadulako Journal (Jurnal Kesehatan Tadulako), 5(1), 39-44. https://doi.org/10.22487/htj.v5i1.111.

Diniyah, A. N., Akbar, G. A. M., Akbar, P., Nurjaman, A., \& Bernard, M. (2018). Analisis Kemampuan Kemampuan Penalaran dan Self Confidence Siswa dalam Materi Peluang. Journal on Education, 1(1), 14-21. https://doi.org/10.31004/joe.v1i1.5.

Fadlillah, M. F. (2018). Peran komunikasi organisasi dengan Self Awareness pada anggota Komunitas Independent Megapro Lumajang [Undergraduate, Universitas Islam Negeri Maulana Malik Ibrahim]. http://etheses.uin-malang.ac.id/10961/.

Fitri, E., Zola, N., \& Ifdil, I. (2018). Profil Kepercayaan Diri Remaja serta Faktor-Faktor yang Mempengaruhi. JPPI (Jurnal Penelitian Pendidikan Indonesia), 4(1), 1-5. https://doi.org/10.29210/02017182.

Fitriana, Farida, U., \& Abrianto, T. H. (2018). Pengaruh Motivasi, Self Awareness Dan Komunikasi terhadap Disiplin Kerja Karyawan di Perusahaan Daerah Air Minum (Pdam) Kabupaten Ponorogo. Asset: Jurnal Ilmiah Bidang Manajemen dan Bisnis, 1(2), 11-23. http://dx.doi.org/10.24269/asset.v1i2.2557.

Fluerentin, E. (2012). Latihan Kesadaran Diri (Self Awareness) dan Kaitannya dengan Penumbuhan Karakter. Jurnal Inspirasi Pendidikan, 1(1), 9-18. https://doi.org/10.21067/jip.v1i1.472.

Frankel, J., \& Wallen, N. (1993). How to Design and Evaluate Research in Education (2nd ed.). McGrawHill Inc.

Govender, D. B. (2017). In times of uncertainty, using self-awareness and strategic foresight to build trust [Mini Dissertation, University of Pretoria]. https://repository.up.ac.za/handle/2263/59833.

Gunawan, D. (2011). Model Bimbingan Karir Komprehensif untuk Pengembangan Karir Siswa Tunarungu. JASSI Anakku: Jurnal Asesmen dan Intervensi Anak Berkebutuhan Khusus, 10(1), $51-59$. 
Hasanah, H. (2015). Pengaruh Komunikasi Interpersonal dalam Menurunkan Problem Tekanan Emosi Berbasis Gender. 11(1), 51-74.

Hilapok, M. O. (2017). Self Awareness dan Implikasinya pada Usulan Topik Program Pengembangan Diri (Studi Deskriptif pada Mahasiswa Program Studi Bimbingan dan Konseling Angkatan 2014 Universitas Sanata Dharma Yogyakarta) [Sanata Dharma University]. https://repository.usd.ac.id/9225/.

Indrayati, N., Iqomh, M. K. B., \& Fahdiyah, H. (2021). Penerapan Komunikasi Efektif Orang Tua untuk Pencegahan Kekerasan Verbal pada Anak. Jurnal Dikemas, 1(1), 5-12.

Khoriroh, N. (2018). Pengaruh Kepercayaan Diri dan Keterampilan terhadap Kemampuan Public Speaking Mahasiswa Program Studi Pendidikan Administrasi Perkantoran Fakultas Ekonomi Universitas Negeri Yogyakarta [Universitas Negeri Yogyakarta]. https://eprints.uny.ac.id/56244/.

Maharani, L., \& Mustika, M. (2016). Hubungan Self Awareness dengan Kedisiplinan Peserta Didik Kelas VIII di SMP Wiyatama Bandar Lampung (Penelitian Korelasional Bidang Bk Pribadi). KONSELI: Jurnal Bimbingan Dan Konseling (E-Journal), 3(1), 57-72. https://doi.org/10.24042/kons.v3i1.555.

Mastiara. (2017). Hubungan Antara Harga Diri Dan Kepercayaan Diri Dengan Kemampuan Komunikasi Interpersonal Pada Siswa Kelas VII SMP Negeri 2 Semarang. Universitas Negeri Semarang.

Mesta Limbong. (2017). Pengembangan Diri Mahasiswa Di Fakultas Keguruan Iimu Pendidikan Universitas Kristen Indonesia (FKIP - UKI). Jurnal Bimbingan dan Konseling, 6(2), 248-255.

Mirhan, J. B. K. J. (2016). Hubungan antara Percaya Diri dan Kerja Keras dalam Olahraga dan Keterampilan Hidup. Jorpres (Jurnal Olahraga Prestasi), 12(1), 86-96. https://doi.org/10.21831/jorpres.v12i1.9499

Mitayani, F. (2017). Kecerdasan Emosional Perawat dengan Kepuasan Pasien di RSUP Dr. M. Djamil Padang. Menara Ilmu, 11(75), Article 75. https://doi.org/10.33559/mi.v11i75.164.

Nurika, B. (2016). Hubungan Antara Konsep Diri Dengan Kepercayaan Diri Remaja Yang Mengunggah Foto Selfie Di Instagram (Ditinjau Dari Jenis Kelamin Dan Usia) [S1, Universitas Muhammadiyah Surakarta]. http://eprints.ums.ac.id/48321/.

Purnomo, D. P., \& Harmiyanto, H. (2016). Hubungan Keterampilan Komunikasi Interpersonal dan Kepercayaan Diri Siswa Kelas X SMAN 1 Garum Kabupaten Blitar. Jurnal Kajian Bimbingan Dan Konseling, 1(2), 55-59. http://dx.doi.org/10.17977/um001v1i22016p055.

Puspitasari, R. P., \& Laksmiwati, H. (2012). Hubungan Konsep Diri dan Kepercayaan Diri dengan Kemampuan Komunikasi Interpersonal pada Remaja Putus Sekolah. Jurnal Psikologi: Teori \& Terapan, 3(1), 58-66. http://dx.doi.org/10.26740/jptt.v3n1.p58-66.

Putri, S. A. P. (2012). Karir dan Pekerjaan di Masa Dewasa Awal dan Dewasa Madya. 3(3), 193-212.

Rakhmat, J. (2011). Psikologi Komunikasi. PT. Remaja Rosdakarya.

Riyadi, A., \& Hasanah, H. (2015). Pengaruh Kesadaran Diri dan Kematangan Beragama terhadap Komitmen Organisasi Karyawan RSUD Tugurejo Semarang. Psympathic: Jurnal Ilmiah Psikologi, 2(1), 102-112. https://doi.org/10.15575/psy.v2i1.451.

Sahputra, D., Syahniar, S., \& Marjohan, M. (2016). Kontribusi Kepercayaan Diri dan Kecerdasan Emosi terhadap Komunikasi Interpersonal Siswa serta Implikasinya dalam Pelayanan Bimbingan dan Konseling. Konselor, 5(3), 182-193. https://doi.org/10.24036/02016536554-0-00.

Salim, A. (2015). General Self-Confidence and Its Implication on Students' Achievement in Oral Presentation. JEELS (Journal of English Education and Linguistics Studies), 2(2), Article 2. https://doi.org/10.30762/jeels.v2i2.95.

Sastrawinata, H. (2011). Pengaruh Kesadaran Diri, Pengaturan Diri, Motivasi, Empati, Dan Keterampilan Sosial Terhadap Kinerja Auditor Pada Kap Di Kota Palembang. Sosialita, 1(2), 119. 
Suhanti, I. Y., Dwi Nikmah Puspitasari, \& Rakhmaditya Dewi Noorrizki. (2018). Keterampilan Komunikasi Interpersonal Mahasiswa UM. Perkembangan Masyarakat Indonesia Terkini Berdasarkan Pendekatan Biosikososial.

Vega, A. D., Hapidin, H., \& Karnadi, K. (2019). Pengaruh Pola Asuh dan Kekerasan Verbal terhadap Kepercayaan Diri (Self-Confidence). Jurnal Obsesi: Jurnal Pendidikan Anak Usia Dini, 3(2), 433-439. https://doi.org/10.31004/obsesi.v3i2.227. 